\title{
Determining Career Path that Fits State-Owned Corporations
}

\author{
Suharto \\ College of Economics IEU Surabaya, Indonesia \\ suharto@ieu.ac.id \\ Yohanes Wibowo \\ College of Economics IEU Surabaya, Indonesia \\ johaneswibowo@ieu.ac.id
}

\begin{abstract}
Background: In a business, there are two side of stake holders that are important and must be fulfilled what their expectations. They are employees and owners. The owner expects a good return, so, they expect the effective and efficient of a company and the finally will find a good return. Meanwhile one of employee's expectation particularly in state-owned corporation is career. Several kind of career path combination is implemented in the state-owned corporation. We have to determine the career path combination that able to accommodate both of the requirements. The objective of this paper is identifying whether the kind of career path combination model that suitable for be implemented in state-owned corporation. Method: This paper used qualitative approach. Data and information collected by searching internet, interview with employees, and study literature even text book and journal. Result: There are several model of the career path combination that suitable to be implemented in state-owned corporation. The model that be selected depend on the kind of business what the company works. All of kind career paths have benefit and weakness. For reducing the weakness, it must be adjusted in several aspect of this career path combination.
\end{abstract}

Keywords - career, path, corporation

\section{INTRODUCTION}

\section{A. Background}

Referring to the preliminary survey, the stated owned corporations have implemented several career paths model. Two of stakeholders concern to the career path, namely are the owner of corporation (management) and employees. The owner of corporation concerns to career path. The career path determines amount of job position, and job position means spending of cost. The employees also concern to the career path. The career path determines amount of job position opportunities. For finding the profit, a company must find revenue as much as possible and reducing the cost. For reducing cost, the career path must be slim. The employees prefer the career path which has many positions. This is a dilemma. The owner prefers the slim career path, but the employees prefer the career path which has many job position. Meanwhile all companies have employees as prime mover of all their activities. Therefore, the management or the companies must keep their work motivation in order to they always work to finishing their targets by high spirit.
There were many of previous researchers that have researched about career path. First, he focused on career systematization issues that be related to career development [1]. Second, he focused on the relationship between the three components model of commitment, workplace stress and career path [2]. Third, they discussed about career as a life-long process which leads to an individual's self-improvement [3]. Forth, they discussed about relationship between career path and Information System staff [4]. Fifth, they focused on external factors that guide individuals through Information System staff's careers [5]. Sixth, they discussed about career path for retaining good workers [6]. Seventh, he mentioned that managers must be able to identify and communicate career opportunities that are tailored to the skills and experience of each employee [7]. Eighth, he stated that a corporations must have a clear career map for its employee and the manager must have ability to explain to the employee where they are [8]. Ninth, they focused on career path especially for female employees [9]. Tenth, they discussed about correlation between satisfaction and career stage of information system staff. They also suggested to provide career path especially for information system staff [10]. Eleventh, they discussed about development of self-managed career path [11]. Twelfth, they discussed about relationship among career path, job dissatisfaction, stress, and turn over [12]. Thirteenth, she focused on career path associated to performance [13].

It is different with this paper. All of the authors above talked about career path associated only to employee's interests. Meanwhile, this paper focused on career path was associated to management (owner) and employee's interests.

Referring to story above, it can be stated the problem as follows:

How did the corporations determine the career path model?

What is the model of career path that can be implemented in state-owned corporation for accommodating the management and employee's need?

\section{B. Objective}

The objective of this paper is:

To analyze how did the corporations determine the career path model. 
Finding out the model of career path that can be implemented in state-owned corporations for accommodating the management and employee's need,

\section{Benefit}

After this paper finished, hopefully:

This paper can give knowledge about determining the career path model.

This paper can give input to the company's management in determining the model of career path for accommodating the need of employees and companies.

\section{LITERATURE REVIEW}

\section{A. Company's Need}

In general a company is established for finding a good profit or good return [14]. To find a good profit or return, the company should find a lot of revenue and spend little cost. In principle a corporation prefers cost efficiency [15]. Getting good revenue and little cost means that the company has good performance or achieving success. Since the human resources are prime mover of all activities in company, so, successfulness of company will be achieved if it obtain supported from its human resources [16].

\section{B. Employee's Need}

One of employees or people need is recognition [17]. In a company, one of recognition need belong to employees is job position level or career [18]. A good management of career path reduces turnover [19]. Employees will have high motivation if their need possibly can be achieved [20].

\section{Career Path}

There are three career path in a corporation. It is grading path, structural path, and function or profession path [21]. There are several kinds of grading path. For example, the state employee uses grading I-a, I-b, I-c, Id, II-a, IV-a, IV-b, IV-c, IV-d, and IV-e. The electricity corporation uses grading start from 1, 2, $3 \ldots . .24$, and 25. The telecommunication corporation grading starts from 1,2,3, and 7.

The example of position in structural path is assistant manager, manager, senior manager, director, and president director. Meanwhile the example of position in area model structural path is assistant manager sub district, manager district, senior manager province, director, and president director. The example of position in functional or professional path is technician, senior technician, engineer, and senior engineer.

\section{State-Owned Corporation}

The state-owned corporation is company which all of its share or minimum 51 percent belong to government [22]. Several of state-owned corporation have product in monopoly market and several of others have product in competition market. Several companies use information technology for production equipment and several of others use engine as production equipment.

\section{METHOD}

The title of this paper is "Determining of Career Path that Fits on State-Owned Corporations". The aim of this paper is to identify the employee's career path that suitable to implement in Indonesia State-Owned Corporations.

This paper uses Strength-Weakness-Opportunity-Threat analyzing tool for analyzing the information. After setting the problem statement, the first step in this paper was identifying the career path that right now implemented in the state-owned corporation in Indonesia. The location of research is companies that having industry of oil, electricity, and telecommunication in Indonesia. We also explored the other information that can be considering why the companies use the current career path. The data and information that had been collected will be analyzed what the background why this career path model be implemented. For analyzing of models that able to accommodate the interests of the company and the employee, had been used Strength-Weakness-Opportunity-Threat analyze model.

\section{RESULT AND DISCUSSION}

\section{A. Career Path and Information in Corporation of Telecommunication Industry}

The telecommunication industry has ever implemented several model of career path. Before year 1990, they used combining grading model and structural model. In that time, they had conventional equipment system with electricalmechanical system. Their market was monopoly. In year 1990 to 2005, they used combining structural model and functional model. In this period used more modern equipment. In this period, the industry also starts to recognize the mobile telecommunication (cellular) and internet. The technology of system was combining electrical-mechanical and information technology. Their market was still monopoly. In year 2006 to 2015 , they used only structural model of career path. In this period, they used equipment fully information technology with Internet Protocol Network system. In this period the industry starts to recognize the triple player. The triple player is kind of telecommunication feature. They are voice (telephone), data (internet), and image or video (TV, video demand, and others). Their market at that time started to go in competition market (oligopoly/many player).

\section{B. Career Path and Information in Corporation of Electricity Industry}

The corporation of electricity industry uses combination of structural and function model of career path. They use mechanical and engine for production equipment. Industry of electricity still has monopoly market, because only one company produces this product.

\section{Career Path and Information in Corporation of Oil Industry}

The corporation of oil industry uses combination of structural and functional model for its career path. They use mechanical and engine for their production equipment. Their market is also still monopoly. 


\section{The Result of Interview with the Employee.}

Referring to the result of interview with employees of telecommunication industry stated that most of employees that have ages below 30 year old. They prefer to work in competitive career. They like structural model for their career path. Meanwhile, the older employees (above of 30 year old), they like to combining of structural and functional model for their career path.

All respondents of oil industry stated that they enjoy with the current career path namely combination of structural and functional model.

All respondents of electricity industry also stated that they enjoy with the current career path namely combining of structural and functional model.

\section{E. The Analyzing of Determining Career Path in the Indonesia Stated-owned Corporation}

Referring the above illustration, it was shown the career path model that implemented in the Indonesia stated-owned corporation depends on their business. The corporations those using information technology for their production equipment and having competition market use structural model for their career path model. Meanwhile the corporations that most of their equipment use mechanical and engine and also have monopoly market using combination of structural and functional model for their career path model. The corporations that use low technology, have monopoly market, and usually their employee is government employee using combination of grading and structural model for their career path. So, the implementation of career path in the stated-owned corporation is determined by what the business of the corporation. The production equipment and status market determines the implementation of career path.

\section{F. The Business Analysis}

There are three model of career path that have ever implemented in Indonesia stated owned corporation. They are combination of grading and structural model, combination of structural and functional model, and structural model.

\section{G. The Combination of Grading and Structural Model}

In this model, an employee can increase his grade without increasing the structural position. There is top limited grade depend on the education background. In the certain position on structure organization has criteria of the position grade range (minimum and maximum).

The strength or the benefits of these models are the employees feel calm because they think they are safety on career path. The employees are loyal to the corporation. The work experience is also be appreciated. (The result of interview is in line with the theory). The weakness of this model is the employees don't have spirit to develop them self and to compete each other, instead, this model doesn't establish the competition environment. Referring to illustration above that the combination of grading and structural model prefer is used on social institution, not for a business corporation.

\section{H. The Combination of Structural and Functional Model}

In this model, an employee can increase his position in structural or functional path. He can occupy a structural position if there is a vacancy in a particular position. He can increase his position in functional path if he has a certain qualification that eligible in that position.

Referring the result of observation and interview shown that this model is used by corporation which using mechanical and engine as production equipment. Its market is monopoly. Ninety eight percent of respondents like this model. They have high spirit to develop their skill and knowledge to achieve the higher position.

The strength or the benefits of these model are the employees have high motivation to improve their skill and knowledge. The corporation will have many employees that able to solve the problem in corporation. The weakness of this model is if the corporation cannot control the increasing of employee's job position, so, it will increase the employee's cost and finally will disrupt the financial performance.

\section{The Pure Structural Model}

In this model, an employee only can increase his position if there is vacancy in structural position and he has certain qualification that eligible in that position.

Referring the result of observation and interview shown that this model is used by corporation which using information technology (high technology) as production equipment. Its market is competition market (oligopoly or many player). Only two percent of respondents like this model. Their ages are below twenty seven years old. They still like fight each other.

The strength or the benefit of this model are providing competitive climate among employees to achieve highest performance. This model is more efficient because job position limited.

The weakness of this model is potentially making employees being frustration related their career. The example, there were ten employees had excellent performance. Once time one of them was promoted, since available one vacancy on higher position. Because of this situation, the promoted employee was satisfied, but the nine others were dissatisfied. The dissatisfied nine persons could be counterproductive and influencing the corporation is not optimal.

\section{J. Determining the Appropriate Career Path}

If the employees are satisfied and the spent costs are efficient, so, the corporation is health. The each of three kind of career path combination has benefit and weakness. We will determine which the model that can be improved to become the appropriate model that efficient and making employees satisfied. Referring to description above, it will be identified a model that can be improved to become still be efficient but employee also be satisfied and may accept it.

- The first model (combination of structural and grading). Even though it is accepted by employees but it doesn't establish improvement climate (making lazy employees). It can't be improved. 
- The second model (combination of structural and functional). Most of the employees accept and satisfied with this model. This model also can establish improvement climate. Improvement is in skill and knowledge. The weakness of this model is that if the management can't control the increment of employee level position, it will cause the increment labor cost. This model can be improved by controlling the incremental of function level position. One of the way how to control the incremental employee level position is by making it in line with the incremental profit. It means that their performance is useful for real business.

- The third model (pure structural model). The benefit of this model is efficient. It is not many and limited certain position. It also has high competition climate. But many good employees were dissatisfied because they didn't get position anymore. They did counterproductive. Finally, the corporation potentially getting loss. This model is very rigid and cannot be improved.

\section{CONCLUSION AND SUGGESTION}

\section{A. CONCLUSION}

Referring to elaboration above, the author can conclude as follows:

1) The determining of career path in stated-owned corporation is determined by the business of the corporation. It depends on the status of market and the production equipment.

2) The career paths that suitable for stated-owned corporation is follows.

- The first model (combination of structural and grading) is suitable for corporation that has conventional technology and has monopoly market.

- The second model (combination of structural and function) is suitable for corporation that has high technology. The market in the second model can be monopoly or competition. For perfection this model is necessary to add rules on the promotion functional requirements associated with real business results.

- The third model (pure structural model) is suitable for corporation that has information technology and young employees. The corporation must have capability to seek employee easly because this model has impact to the employees easy to move (high turnover).

\section{B. SUGGESTION}

In business condition such as be current right now, where is almost of kind market going to competition (global free trading) and equipment going to high technology, the suitable model of career path is combination of structural and functional with improvement of functional promotion regulation.
Particularly the corporations those having dominant young employees, they can use pure structural model but much provide retention program.

\section{REFERENCES}

[1] Kozlova, OP, "Employee's Career Path: Classification on Systematization Bases", Economic and Social Development: Book of Proceedings, 2013, p115.

[2] Nasr, Linda, "The Relatinship Between the Three Components Model of Commitment, Workplace Stress and Career Path Application to Employees in Medium Size Organizations", Journal of Organizational Culture, Communication and Conflict, vol. 16.1, 2012, p71-87.

[3] Matulcikova, Marta; Brevenikova, Daniela D, "Career Life Long Sef Improvement Process", European Scientific Journal, vol. 10.25, 2014.

[4] Jiang, James; Klein GCary, "Supervisor Support and Career Anchor Impact on the Career Satisfaction of the Entry Level Information System Professional", Journal of Management Information System, vol. 16.3, 2000, p219-240.

[5] Crepeau, Raymond G; Crook, Connie W; Goslar, Martin D; McMurtrey, Mark E, "Career Anchors of Information System Personnel", Journal of Management Information Systems, vol. 9.2, 1992, p145.

[6] Chang, Christina Linghsing; Chen, Victor; Klein, Gary; Jiang, James, "Information System Personnel Career Anchor Changes Leading to CCareer Changes", Journal of Information System, vol. 20.1, 2011, p103-117.

[7] Watson, Towers, "North American Employers' Career Management Programs Falling Short, Creating Attraction Risks", Journal of Enginnering, 2013, p858.

[8] Pratt, Mary K., "Career Mapping Done Right", Computerworld, vol. 46.21, 2012, p24-25.

[9] Lagasi, Florence Elma; Buba, Eldah Ephraim, "Examining Challenges of Female Gender Employee's and Career Progression in the Hotel Industry", World Scientific News, vol. 25, 2016, p17-24.

[10] Hsu, Maxwell K.; Chen, H.G.; Jiang, James J.; Klein, Gary, "Career Satisfaction for Managerial and Technical Anchored IS Personnel in Later Career Stages", Database for Advances in Information Systems, vol. 34.4, 2003, p64-72.

[11] Yildiz, Didem; Beskese, Ahmet; Bozbura, Tunc Faik, "A Hybrid Decision Support Model for Self Managed Career", Kybernetes, Emerald Group, vol. 44.4, 2015, p555-575.

[12] Chandio, Javed Ahmed; Jhatial, Ashique Ali; Mallah, Rafia, "Modelling the Relationship of Unclear Career Development with Job Dissatisfaction, Job Stress and Employees' Turnover Intention", International Research Journal of Arts and Humanities, vol. 41.41, 2013 p57-70.

[13] Lareau, Jamie, "Dealers Aim Higher to Fill Jobs: The Goals: Hire More College Grads and Put Them on Career Paths", Automotive News, vol. $86.6509,2012, \mathrm{p} 3$.

[14] Stengel, Donald N., "Managerial Economics Condepts and Principles", Business Expert Press, 2011.

[15] Reilly, Robert F., "Considering the Corporation Construction Company Conversion to Tax Pass-Through Entity Status", Construction Accounting and Taxation, vol. 22.5, 2012, p14-20,22-25.

[16] Robbins, Stephen P., "Organizational Behavior”, Prentice Hall, 2001.

[17] Maslow, A.H., "Motivation and Personality", Pearson Education, 1987.

[18] Alavi, S.B.; Moteabbed, S.H.; Arasti, M.R., "A Qualitative Investigation of Career Orientations of a Sample of Iranian Software Engineers", Computer Science and Engineering, Electrical, vol. 19.3, 2012, p662673.

[19] Altepeter, Andrew, "How to Develop a PCI Compliance Program and Take a Step on the IG Career Path", Information Management, vol. 47.6, 2013, p26-29,31-47.

[20] Armstrong, Michael, "Human Resources Management Practice”, Kogan Page, London, 2007. 
[21] Dessler, Gary, "Human Resources Management", Pearson Education Limited, Harlow, England, 2011.
[22] No Author, "Laws of the Republic of Indonesia Number 19 of 2003 on State Owned Enterprises", Secretariat of State of the Republic of Indonesia, Jakarta, 2003. 